\title{
INFORMATION SYSTEMS SUCCESS MODELS IN THE E-LEARNING CONTEXT: A SYSTEMATIC LITERATURE REVIEW
}

\author{
Darko Stefanovic, Ivana Spasojevic, Sara Havzi, Teodora Lolic \& Sonja Ristic
}
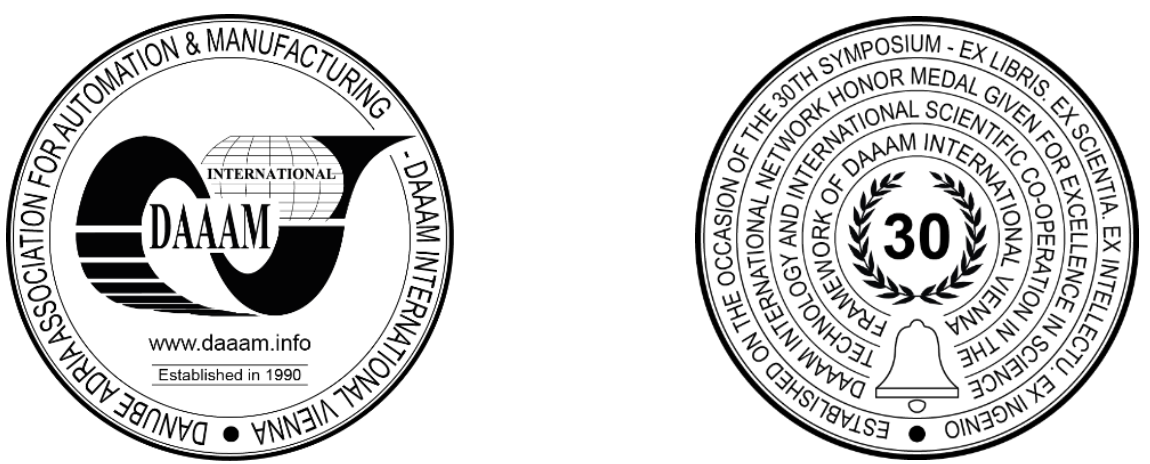

This Publication has to be referred as: Stefanovic, D[arko]; Spasojevic, I[vana]; Havzi, S[ara]; Lolic, T[eodora] \& Ristic, S[onja] (2020). Information Systems Success Models in the E-Learning Context : A Systematic Literature Review, Proceedings of the 31st DAAAM International Symposium, pp.0555-0564, B. Katalinic (Ed.), Published by DAAAM International, ISBN 978-3-902734-29-7, ISSN 1726-9679, Vienna, Austria

DOI: $10.2507 / 31$ st.daaam.proceedings.077

\begin{abstract}
Researchers face a severe challenge when measuring and evaluating the success of information systems. After DeLone and McLean proposed the Information System (IS) success model, it became an important topic of interest. Since then, updates of the model have been proposed, as well as other models for measuring IS success. The rapid growth of elearning system usage in the last few years led to high popularity in research on IS success models in the context of elearning. However, as far as we are aware, there are no literature studies on IS success models in the context of elearning. This study uses a systematic literature review to examine different approaches to measuring IS success in the context of e-learning. The results show that in most cases, e-learning system success was investigated by applying the DeLone and McLean IS success model, Technology Acceptance Model (TAM), by Davis, as well as proposed new hybrid models, which are a mix of multiple models. The biggest shortcoming in the literature is the lack of longitudinal research. The results of this study will add to the existing knowledge of past studies, which have incorporated the IS success in the e-learning context.
\end{abstract}

Keywords: Information Systems Succes Measurement; E-Learning; Systematic Literature Review; Models for Measurement Success;

\section{Introduction}

Advances in technology development and innovations led to a high growth rate of information systems utilisation in all facets of life. One of the aspects that have been significantly emphasised in recent years is the use of technology in learning, especially in the context of e-learning systems. Nowadays, in order to keep competitiveness, one of the critical advantages of higher education institutions could be the usage of technology in education, as well as information systems. For these systems to thrive, they need to be evaluated. Researchers face a severe challenge when measuring and evaluating the success of information systems. Various models have been proposed for measuring IS success. This study uses a systematic literature review by Kitchenham [1] to examine different approaches to measuring information systems (IS) success in the context of e-learning. 
The paper is organised as follows. In Section 2, information system success measurement models are described, as well as the e-learning concept. Systematic literature review (SLR) methodology alongside with the planning and conducting the review phase employed in the current study are presented in Section 3. Following that, in Section 3 are reported the SLR results, and their discussion is given in Section 4. Section five concludes the study, its limitations, and suggests future researches.

\section{Background and Related Work}

Keen [2] described the mission of IS as: "the effective design, delivery, use, and impact on information technologies in organisations and society. The term 'effective' seems key." Based on Keen's view of information systems, the evaluation of the "effectiveness" or "success" of information systems is an essential aspect of the information systems field in both research and practice.

For the past thirty years, researchers have been debating the success of information systems. The research began with the DeLone and McLean IS Success Model. DeLone and McLean [3] proposed the IS Success Model in 1992. Based on the six measures: system quality, information quality, use, user satisfaction, individual impact, and organisational impact. Over time many researchers proposed modifications of this model. They also suggested other levels of IS impact. Based on these suggestions, in 2003. DeLone and McLean [4] proposed the updated IS Success Model, where they grouped all the impact measures into a category called "Net Benefits". The proposed model is shown in Fig. 1.

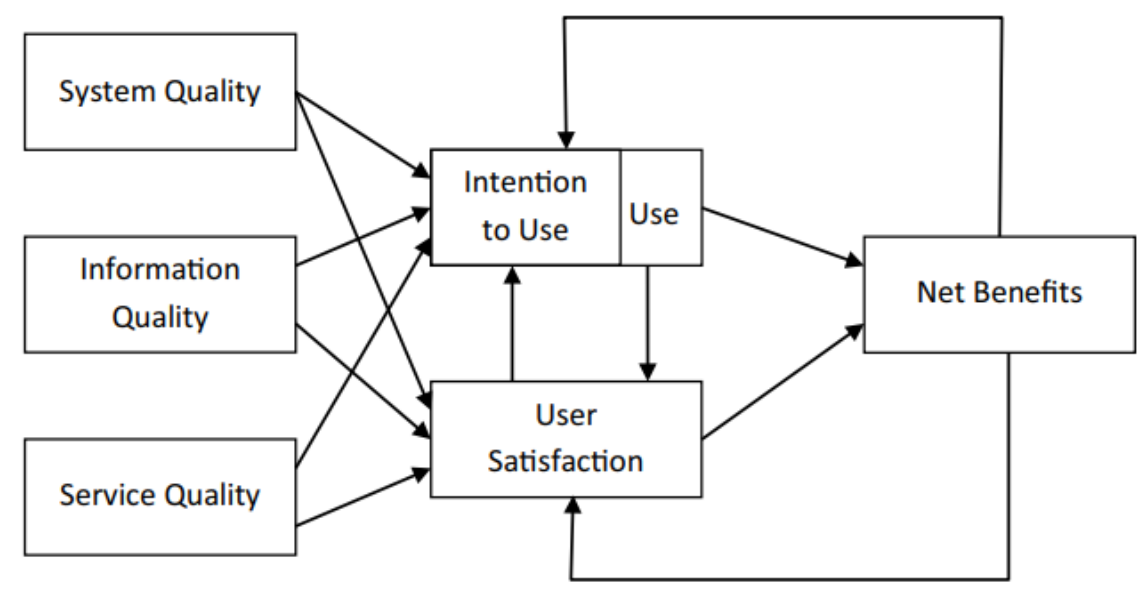

Fig. 1. Updated DeLone and McLean IS Success Model [4]

Numerous scientists and researchers have examined the success of various information systems, such as the Internet presentation [5], knowledge management system [6], e-government system [7], and industrial systems [8], as well as elearning systems in educational institutions [9].

The success of the information system is, in most cases, very subjectively defined. For example, from the user's point of view, a successful information system is one that responds quickly to requirements, an information system that improves the performance of users work. The view of the success of the information system depends on its stakeholders. For example, organisations view the success from the aspect of profit, the realisation of competitive advantage, or how users accept it. If users do not accept the information system, it will be challenging to use it in order to contribute to business improvement.

In the last few years many researchers conducted different studies in field of measuring the success of e-learning systems by using different models or developing new ones. In this paper, those publications will be presented. The implementation of information systems comes with a certain risk. In order to reduce it, it is necessary to act preventively in order to find weaknesses. Most often, weaknesses of implemented IS are related to the limitations of the company in the terms of lack of competent staff, time or money [10].

Information technology (IT) has become the key tool which affects efficiency and competitiveness of an organisation. It is most commonly used to gather information which is useful in making business strategies and decisions. Significance of information technology usage can be emphasized with a fact that companies became so dependent on it that they are often referred as "information organisation" [11]. IT is the fundamental tool of many organizations' strategies and key factor that enable their efficient work and their competitiveness in the market. It helps in gathering data and creating information that is useful in making business decisions. IT today becomes a strategic element in the development of the organization and the society in general., Today, the organizations become so dependent on information processes, flow of information and the application of modern technologies that they can rightly be called an "information organizations". 


\section{Methodology}

Research goal was to gather insightful information about information systems success models which are used in order to measure success of the e-learning systems. In order to conduct this literature review, we used guidelines by Kitchenham, B. [1]. The literature review is focused on a set of research questions, as well as inclusion and exclusion criteria.

\subsection{Planning the Review}

The initial stage of the review planning phase should be the elaboration of the systematic need for the literature review in a particular subject [1]. To present the need and the motivation for conducting the SLR, authors should review the existing literature on the relevant topic. Accordingly, no explicit, systematic literature reviews are presenting the information systems success measurement in the context of e-learning. Based on the guidelines from Kitchenham [1] the following research questions are formulated:

$R Q 1$ : Which models are the pillars in the field of measuring e-learning information system success?

$R Q 2:$ Are there any proposed new models that can be applied?

$R Q 3:$ Are there any studies that examine the success of different e-learning information systems?

For this literature review, the following databases were searched:

- Scopus,

- Web of Science, and

- Google Scholar.

Elsevier's Scopus is the largest abstract and citation database of peer-reviewed literature. Web of Science provides access to reliable, integrated, and multidisciplinary research connected through linked content citation metrics from multiple sources within a single interface. Google Scholar is a web search engine that indexes different types of literature. Search terms defined for search in these databases are presented below:

("Information system success"

OR

"Information system success model"

OR

"Information system success measurement model")

AND

("Higher education" OR College OR University)

AND

(E-Learning OR "Online learning" OR "Web-based Learning")

AND

PUBYEAR $>2008$

AND

Language=" English"

The inclusion criteria defined for this review are:

IC1: Paper has to present a study on using IS success models with the purpose of measuring existing e-learning systems success or developing a new IS success model that measures e-learning system success.

IC2: The publication has to include detailed information about the developed model or procedure.

Exclusion criteria defined for the review are:

$E C 1$ : Duplicate papers found in different databases should be removed.

EC2: If one author has more than one paper regarding the same approach, only one paper should be included in the review.

EC3: If a paper is focused only on information system success, but not in the context of e-learning, the paper should be removed.

For this literature review, the data extraction strategy was developed. For each primary study, the following features will be extracted in order to answer the research questions:

1. Publication year and source type;

2. Used/adjusted/developed model;

3. Feasibility and applicability of the approach;

4. Genericity of the approach and information systems; and

5. Applicability for non-experts. 


\subsection{Conducting the Review}

The first activity of conducting the review phase is the identification of the research, i.e., primary studies that will be included in the systematic literature review. Primary studies are identified in accordance with inclusion and exclusion criteria, defined in the review protocol. The search flow is presented in Table 1.

\begin{tabular}{|c|c|c|c|c|}
\hline Resource & Results found & Duplicated content & Initial selection & Final selection \\
\hline Scopus & 734 & 324 & 58 & 20 \\
\hline Web of Science & 454 & 211 & 31 & 15 \\
\hline Google Scholar & 873 & 521 & 23 & 10 \\
\hline
\end{tabular}

Table 1. Flow of the exclusion and inclusion process

Criteria followed for inclusion and exclusion are defined in the previous section of this paper. After applying the previously defined search string to seek through databases, identification resulted in 2061 primary studies, summary. At the screening stage, the first step was to remove the duplicated records from different databases, where 1056 duplicates were found, and they were excluded from further research. Based on the second exclusion criteria, 11 papers were excluded from the selection. By applying third exclusion criteria, we excluded 56 papers, since they presented information systems success measurement and models, but not in the context of e-learning. In the end, 45 primary studies are included for the final analysis in the review.

Data Extraction and Summarisation: Primary studies which are selected in the previous phases of the systematic literature review are summarised and presented in the following chapter using the data extraction strategy. The analysis of selected papers is complemented with tables and graphs which allow visual representation of primary studies based on the data extraction criterion. Nearly all of the reviewed primary studies were carried out in the last ten years, while only two of them were conducted in 2009. As is displayed in Table 2, the majority of the papers were published in the last five years (73\%). This data is visually represented in Fig. 2. Two peaks in the number of conducted studies per year happened, first in 2012 and second in 2018, which can be seen in the line diagram and in Table 2.

\begin{tabular}{|c|c|c|c|}
\hline Year & Primary studies & $\begin{array}{c}\text { Number of } \\
\text { studies }\end{array}$ & $\%$ \\
\hline 2009 & {$[12],[13]$} & 2 & 4 \\
\hline 2010 & {$[14],[15]$} & 2 & 4 \\
\hline 2011 & {$[16]$} & 1 & 2 \\
\hline 2012 & {$[17],[18],[19],[20],[21],[22]$} & 6 & 13 \\
\hline 2013 & {$[23],[24]$} & 0 & 0 \\
\hline 2014 & {$[25],[26],[27],[28]$} & 2 & 4 \\
\hline 2015 & {$[29],[30],[31],[32],[33]$} & 4 & 10 \\
\hline 2016 & {$[34],[35],[36],[37],[38]$} & 5 & 11 \\
\hline 2017 & {$[48],[49],[50],[51]$} & 5 & 11 \\
\hline 2018 & {$[52],[53],[54],[55],[56]$} & 9 & 20 \\
\hline 2019 & & 4 & 10 \\
\hline 2020 & & 5 & 11 \\
\hline
\end{tabular}

Table 2. Distribution of primary studies per year

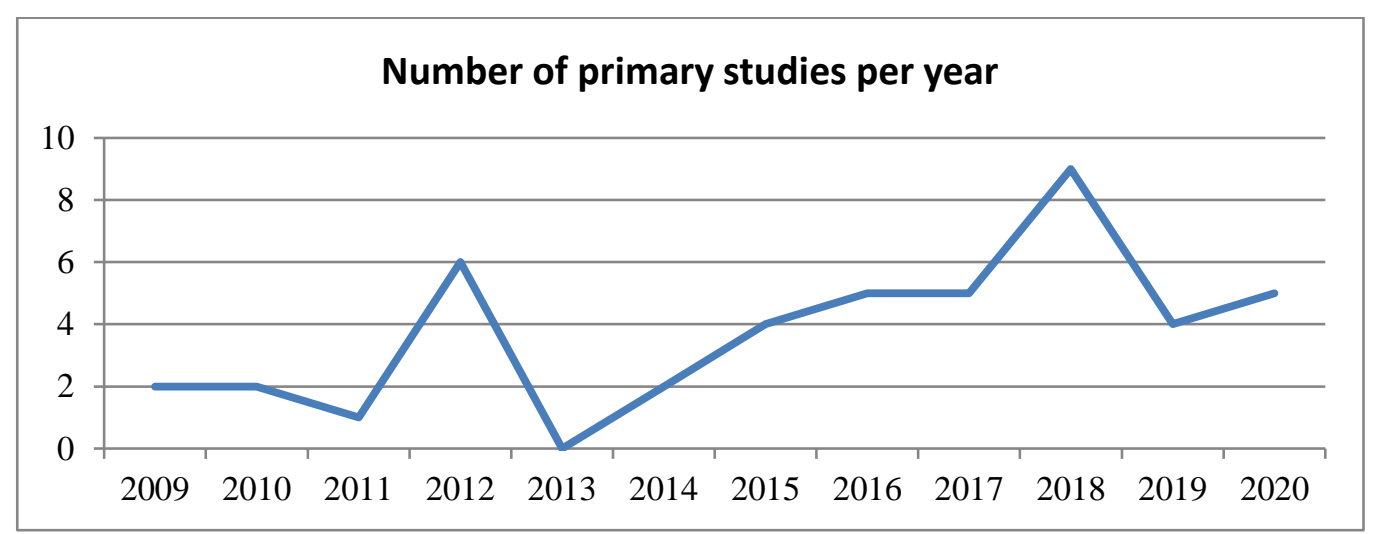

Fig. 2. Visual representation of distribution of primary studies per year 
Source types of the primary studies are presented in Table 3, showing that a majority of the papers (96\%) were published as journal articles while the rest of them (papers [51] and [21]) were conference papers.

\begin{tabular}{|c|c|c|c|}
\hline Source type & Primary studies & $\begin{array}{c}\text { Number of } \\
\text { studies }\end{array}$ & $\%$ \\
\hline \multirow{3}{*}{ Journal article } & {$[52],[53],[44],[34],[54],[48],[40],[49],[41],[29],[50],[30],[42]$,} & & \\
& {$[35],[36],[55],[43],[44],[25],[17],[56],[16],[26],[31],[12],[27]$,} & 43 & 96 \\
& {$[23],[45],[46],[18],[37],[47],[32],[14],[28],[13],[24],[15],[33]$,} & & \\
\hline Conference paper & {$[19],[20],[38],[22]$} & 2 & 4 \\
\hline
\end{tabular}

Table 3. Source types of primary studies

Studies that were selected in the systematic literature review process can also be observed from the aspect of research type and methodology used to conduct those researches. Primary studies grouped by the research type, which was used on the one hand, and the methodology that was used to carry out those studies, on the other hand, are shown in Table 4. Only two of the studies ([29] and [43]) can be categorised as theoretical researches. It is also noticeable in the table that these two studies used neither quantitative nor qualitative methods. Remaining 43 papers are viewed as empirical researches. The results show that $89 \%$ of the reviewed studies were carried out as quantitative research, while $7 \%$ was conducted as mixed research (both quantitative and qualitative methods were used).

\begin{tabular}{|c|c|c|c|c|c|}
\hline \multirow{2}{*}{$\begin{array}{c}\text { Research } \\
\text { type }\end{array}$} & \multicolumn{3}{|c|}{ Primary studies by methodology } & \multirow{2}{*}{$\begin{array}{c}\text { Number of } \\
\text { studies }\end{array}$} & \multirow{2}{*}{$\%$} \\
\hline & Quantitative & Mixed & N/A & & \\
\hline Empirical & $\begin{array}{l}\text { [52], [53], [39], [34], [54], [48], [40], [49], } \\
{[41],[50],[30],[42],[35],[36],[55],[44],} \\
{[51],[25],[16],[26],[31],[12],[27],[23],} \\
{[45],[46],[18],[37],[47],[32],[14],[28],} \\
{[13],[24],[15],[33],[19],[20],[38],[21]}\end{array}$ & $\begin{array}{c}{[17],[56],} \\
{[22]}\end{array}$ & & 43 & 96 \\
\hline Theoretical & & & {$[41],[43]$} & 2 & 4 \\
\hline
\end{tabular}

Table 4. Research types of primary studies

Distribution of the papers based on the type of model that was used for information system success testing is shown in Table 5. Table analysis shows that most of the research was conducted with the usage of the Information Systems Success Model (ISSM), which was initially introduced by DeLone and McLean in 1992 [3] and later updated in 2003 by the same authors [4]. Almost 27\% of the papers (12 of 45 in total) were based on this individual model while, at the same time, $25 \%$ of them (11 of 45 in total) suggested extensions of the basic model with the introduction of new, mediating, variables and factors that can affect the success of an information system for e-learning.

This observed result shows that more than half of the conducted studies (52\%) were based just on DeLone's and McLean's model. On the other hand, as much as $44 \%$ of the primary studies proposed a new model which combines variables and factors from different pillar models to overcome the limitations of those models. There were two of the selected papers, which suggested a completely new model for measuring the success of an e-learning information system $-[52]$ and [30].

\begin{tabular}{|c|c|c|c|c|}
\hline & & Primary studies & $\begin{array}{c}\text { Number of } \\
\text { studies }\end{array}$ & $\%$ \\
\hline \multirow{2}{*}{ ISSM } & Basic model & $\begin{array}{c}\text { [53], [34], [54], [25], [56], [16], [31], [37], [28], [15], } \\
{[20],[22]}\end{array}$ & 12 & \multirow{2}{*}{52} \\
\hline & $\begin{array}{c}\text { Extended } \\
\text { model }\end{array}$ & $\begin{array}{c}{[48],[35],[36],[55],[27],[45],[46],[47],[32],[24],} \\
{[21]}\end{array}$ & 11 & \\
\hline \multicolumn{2}{|c|}{ Combined model } & $\begin{array}{l}\text { [39], [40], [49], [41], [29], [50], [42], [43], [44], [51], } \\
{[17],[26],[12],[23],[18],[14],[13],[33],[19],[38]}\end{array}$ & 20 & 44 \\
\hline \multicolumn{2}{|c|}{ New model } & {$[52],[30]$} & 2 & 4 \\
\hline
\end{tabular}

Table 5. Distribution of primary studies based on the type of model that was used

In most of the reviewed papers which proposed a combined model, a model was the result of a combination of variables from ISSM and Technology Acceptance Model (TAM) - 39\% and 35\%, respectively. Some of the papers also combined the variables from the Task-technology fit model and UTAUT (the Unified Theory of Acceptance and Use of Technology) with previously mentioned models, where each of these models was represented by $6 \%$. 
These models are followed by TPB (Theory of Planned Behaviour), Affinity theory, and Self-efficacy theory with the participation of $4 \%$ by each theory. Only one of the papers ([38]) proposed a combined model that did not use the variables from the ISSM. Similarly, only one of the reviewed studies used variables and factors from the Cultural dimension theory. The percentage share of each of the previously mentioned models in combined models of all reviewed primary studies is shown in Fig. 3, while participation of these models in combined models per study is presented in Table 6.

\begin{tabular}{|c|c|c|c|c|c|c|c|c|}
\hline $\begin{array}{c}\text { Primary } \\
\text { study }\end{array}$ & ISSM & TAM & UTAUT & $\begin{array}{c}\text { Task- } \\
\text { technology fit }\end{array}$ & TPB & $\begin{array}{c}\text { Affinity } \\
\text { theory }\end{array}$ & $\begin{array}{c}\text { Cultural } \\
\text { dimension } \\
\text { theory }\end{array}$ & $\begin{array}{c}\text { Self-efficacy } \\
\text { theory }\end{array}$ \\
\hline$[39]$ & $\mathrm{X}$ & $\mathrm{X}$ & & & & & & \\
\hline$[40]$ & $\mathrm{X}$ & $\mathrm{X}$ & & & & & & \\
\hline$[49]$ & $\mathrm{X}$ & $\mathrm{X}$ & & & & & & \\
\hline$[41]$ & $\mathrm{X}$ & $\mathrm{X}$ & & & & & & \\
\hline$[29]$ & $\mathrm{X}$ & & & $\mathrm{X}$ & & & & \\
\hline$[50]$ & $\mathrm{X}$ & $\mathrm{X}$ & $\mathrm{X}$ & & & & & \\
\hline$[42]$ & $\mathrm{X}$ & $\mathrm{X}$ & & & & $\mathrm{X}$ & & \\
\hline$[43]$ & $\mathrm{X}$ & $\mathrm{X}$ & $\mathrm{X}$ & $\mathrm{X}$ & & & & \\
\hline$[44]$ & $\mathrm{X}$ & $\mathrm{X}$ & & & & & & \\
\hline$[51]$ & $\mathrm{X}$ & $\mathrm{X}$ & & & & & & \\
\hline$[17]$ & $\mathrm{X}$ & & & $\mathrm{X}$ & & & & \\
\hline$[26]$ & $\mathrm{X}$ & & $\mathrm{X}$ & & & & & \\
\hline$[12]$ & $\mathrm{X}$ & $\mathrm{X}$ & & & & & & \\
\hline$[23]$ & $\mathrm{X}$ & $\mathrm{X}$ & & & & $\mathrm{X}$ & & \\
\hline$[18]$ & $\mathrm{X}$ & $\mathrm{X}$ & & & & & & \\
\hline$[14]$ & $\mathrm{X}$ & $\mathrm{X}$ & & & & & & \\
\hline$[13]$ & $\mathrm{X}$ & $\mathrm{X}$ & & & & & & \\
\hline$[33]$ & $\mathrm{X}$ & $\mathrm{X}$ & & & & & & \\
\hline$[19]$ & $\mathrm{X}$ & $\mathrm{X}$ & & & $\mathrm{X}$ & & & \\
\hline$[38]$ & & $\mathrm{X}$ & & & $\mathrm{X}$ & & & $\mathbf{2}$ \\
\hline $\begin{array}{c}\text { Number of } \\
\text { studies }\end{array}$ & $\mathbf{1 9}$ & $\mathbf{1 7}$ & $\mathbf{3}$ & $\mathbf{3}$ & $\mathbf{2}$ & $\mathbf{2}$ & & $\mathbf{2}$ \\
\hline $\boldsymbol{\%}$ & $\mathbf{3 9}$ & $\mathbf{3 5}$ & $\mathbf{6}$ & $\mathbf{6}$ & $\mathbf{4}$ & $\mathbf{4}$ & & $\mathbf{2}$ \\
\hline
\end{tabular}

Table 6. The percentage share of each model in combined models

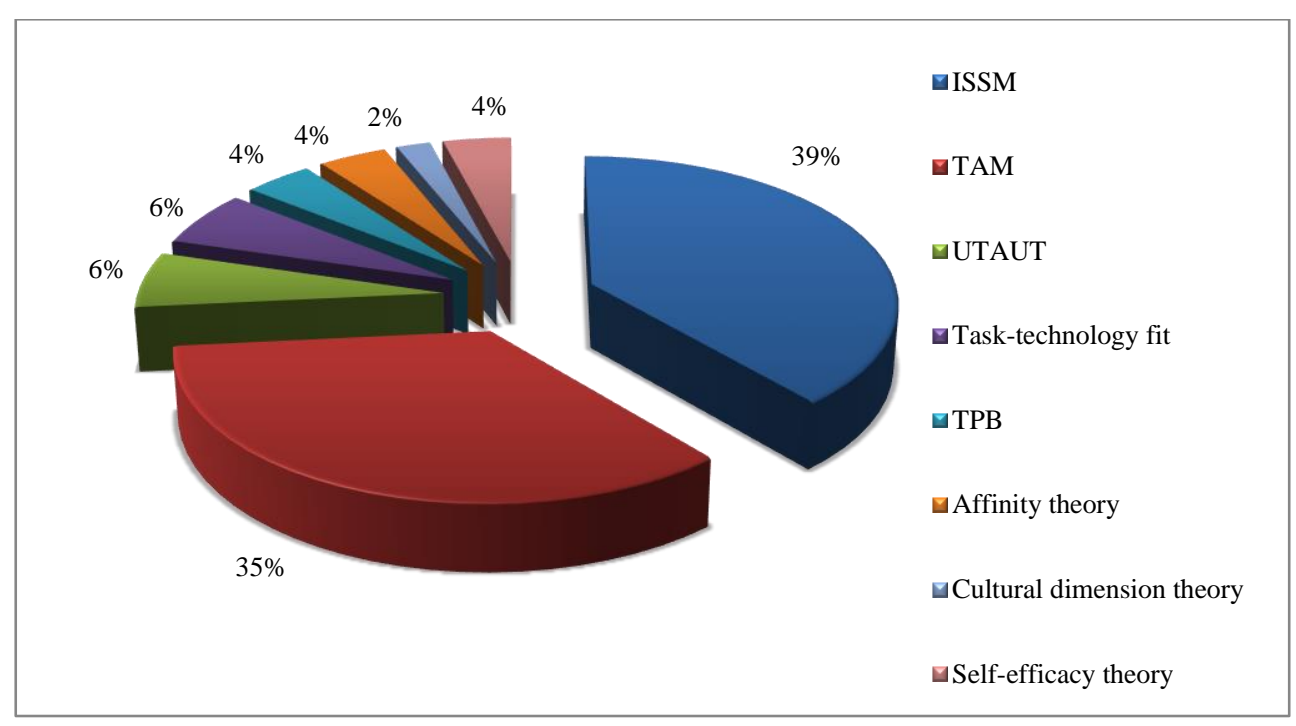

Fig. 3. Visual representation of the percentage share of each model in combined models 
In the following table (Table7) distribution of primarily selected studies based on the e-learning system type is shown. As can be seen from the table, $78 \%$ of the chosen studies were conducted to measure the success of an information system for e-learning in general. Few publications ([41], [36], [51] and [13]) were focused on the usage of e-learning platforms on mobile devices, while six of them empirically tested the usage of digital libraries in the context of education and study literature.

\begin{tabular}{|c|c|c|c|}
\hline E-learning type & Primary studies & $\begin{array}{c}\text { Number of } \\
\text { studies }\end{array}$ & $\%$ \\
\hline & {$[52],[53],[39],[54],[48],[40],[49],[29],[50],[30]$,} & & \\
e-learning & $\begin{array}{c}\text { [35], [55], [43], [44], [17], [56], [16], [26], [31], [12], } \\
{[27],[23],[45],[46],[18],[37],[14],[28],[24],[15],} \\
\end{array}$ & 35 & 78 \\
\hline m-learning & {$[19],[20],[38],[21],[22]$} & & \\
\hline digital library & {$[41],[36],[51],[13]$} & 4 & 9 \\
\hline
\end{tabular}

Table 7. Distribution of primary studies based on the e-learning system type

\section{Discussion}

The results and the findings from the conducted systematic literature review are discussed in this section. The overall impression acquired by analysing results shown in Table 2 and Fig. 2 is that the number of studies carried out per year is going to grow in the future since the curve in the line diagram tends to grow. The reason could be the fact that information systems are more frequently adopted by businesses, governments, educational institutions and individuals over time, which results in a higher number of available e-learning platforms and the higher number of users. This could lead to an improvement in the overall quality of e-learning information systems and success in general, according to Wang and Wang [12]. Following this growth trend as a basis for further research, we noticed that only two research types exist in the reviewed publications. This creates a space for the introduction of longitudinal research. Repeated measurements of the same factors of IS success over a period of time could reveal if there are significant deviations in the results.

The ISSM model is dominantly used for measuring e-learning success according to the results of this study. There were 31 out of 45 primary studies that are at least partly based on ISSM. This fact makes ISSM model a key pillar in the field. It is accompanied by TAM since it has been used as a ground for nine publications. This conclusion answers RQ1.

Similarly, we sought available literature to find the answer to RQ2 and found out that almost half of the examined primary studies did research of e-learning success with a proposition of a combined model. The cause of such a large percentage of these models may be because many authors claim that the application of just one model is not thorough enough to cover all aspects of information systems success that need to be tested. Aldholay et al. [43] claim that individual technical skills or facilitating conditions are important factors that are not covered by ISSM. Furthermore, authors [18] criticise both TAM and ISSM from the aspect of limitations to capture the full picture of factors that influence the information systems success. They assumed that through measuring factors like course quality and selfefficacy, the accuracy of obtained results would be higher.

We analysed the primary studies from the aspect of the e-learning system type and found out that four primary studies were focused on m-learning information systems. Authors of these studies emphasise that more attention should be paid to mobile devices, as it could make the e-learning process more efficient because students would not be dependent on location while the usage could be less time-consuming and cheaper than the usage of classic e-learning information systems [51], [36]. Wang et al. [41] express an opinion that paid m-learning applications are not considered enough in the existing literature in this field. They argue that, although necessary payment of m-learning applications might have a negative effect on the popularity amongst users, this concept potentially means a higher quality of provided service. Moreover, they highlight that learning effectiveness is the most effective measure of success of $\mathrm{m}-$ learning systems, followed by system and information quality.

Given that there are only three primary studies [41], [51], [13] that give a positive answer to all research questions, we can conclude that not enough attention, as of yet, has been paid to finding a model which can be generally applied to measure e-learning information systems success.

\section{Conclusion}

Seeing that e-learning is noticeably emerging worldwide, it is a logical trace of events that the amount of available data and publications in this field is growing. This growth creates the basis for researchers to examine different ways to measure IS success, which consequently may lead to the reduction of the suitability of available models to be used for this purpose. Therefore, this paper presented a systematic literature review of currently explored models used to measure IS success in the context of e-learning. Following research questions were initially formulated and answered in the paper. 
After conduction of the process, we can infer that the current state of the art proposes different models that can be used to measure the success of an information system in the context of e-learning. Some of them, like DeLones' and McLeans' ISSM or Davis' TAM, is dominantly used for this purpose, yet most of them have some limitations.

One of the most important limitations is that majority of the proposed models is not detailed enough to be universally applicable to e-learning systems and that, consequently, they require the introduction of new variables and factors which are to be measured with an aim to overcome these limitations. As can be seen from previously presented results, many researchers already tried to overcome limitations of the individual models by proposing new ones on one the hand or suggesting the integration of variables from different models through the proposition of the hybrid models, on the other hand. However, none of these proposed solutions is generalised as a model that is thorough enough to be universally applicable to all e-learning systems yet.

Nonetheless, another problem that was noticed is that there is no longitudinal research in the reviewed field. Since authors [57] claim that longitudinal studies empower deeper investigation into a certain field and more accurate results, especially when considering the fact that over time individuals can change the impression about different factors which are measured, further researches should pay more attention to this limitation.

Keeping this in mind, as well as the fact that our paper confirms results and limitations found by Al-Kofahi et. al. [57], we can conclude that this paper may be the basis for further research with the aim to improve existing models and develop new ones, since these actions could consequently lead to filling the existing gaps in literature and overcoming existing limitations.

\section{References}

[1] Barbara Kitchenham (2004). Procedures for Performing Systematic Reviews. Keele University

[2] P. G. W. Keen (1980). "Mis research: Reference disciplines and a cumulative tradition," In: ICIS 1980 Proceedings

[3] W. H. DeLone \& E. R. McLean (1992). "Information systems success: The quest for the dependent variable," Inf. Syst. Res., vol. 3, no. 1, pp. 60-95.

[4] W. H. DeLone \& E. R. McLean (2003). "The DeLone and McLean model of information systems success: A tenyear update,” J. Manag. Inf. Syst., vol. 19, no. 4, pp. 9-30.

[5] C. Liu \& A. Kirk (2000). "Exploring the factors associated with Web site success in the context of electronic commerce," Inf. Manag., vol. 38, no. 1, pp. 23-33.

[6] J. H. Wu \& Y. M. Wang (2006). "Measuring KMS success: A respecification of the DeLone and McLean's model,” Inf. Manag., vol. 43, no. 6, pp. 728-739.

[7] Y. S. Wang \& Y. W. Liao (2008). "Assessing eGovernment systems success: A validation of the DeLone and McLean model of information systems success," Gov. Inf. Q., vol. 25, no. 4, pp. 717-733.

[8] Y. S. Wang; H. Y. Wang \& D. Y. Shee (2007). "Measuring e-learning systems success in an organizational context: Scale development and validation," Comput. Human Behav., vol. 23, no. 4, pp. 1792-1808.

[9] J. K. Lee \& W. K. Lee (2008). "The relationship of e-Learner's self-regulatory efficacy and perception of eLearning environmental quality," Comput. Human Behav., vol. 24, no. 1, pp. 32-47.

[10] M. Černá (2014). “Aspects of information management in context with is selection by SME,", Proceedings of 24th DAAAM International Symposium on Intelligent Manufacturing and Automation, Procedia Eng., vol. 69, pp. 745-750, Published by Elsevier Ltd, DOI:10.1016/j.proeng.2014.03.050.

[11] V. Majstorovic \& K. Rakic (2017), "Internet of things and social media: Tools of a successful information organization," Proceedings of 28th DAAAM International Symposium on Intelligent Manufacturing and Automation, pp. 295-298., Published by DAAAM International, ISBN 978-3-902734-11-2, ISSN 1726-9679, Vienna, Austria, DOI: 10.2507/28th.daaam.proceedings.040.

[12] W. T. Wang \& C. C. Wang (2009). "An empirical study of instructor adoption of web-based learning systems," Comput. Educ., vol. 53, no. 3, pp. 761-774.

[13] C. Yi; P. Liao; C. Huang \& I. Hwang (2009). “Acceptance of Mobile Learning: a Respecification and Validation of Information System Success,” Eng. Technol., vol. 41, no. 5, pp. 726-730.

[14] I. A. Almarashdeh; N. Sahari; N. A. M. Zin \& M. Alsmadi (2010). "The success of learning management system among distance learners in Malaysian universities,” J. Theor. Appl. Inf. Technol., vol. 21, no. 2, pp. 80-91.

[15] J. E. Klobas \& T. J. McGill (2010). "The role of involvement in learning management system success," J. Comput. High. Educ., vol. 22, no. 2, pp. 114-134.

[16] H. C. Chang; C. F. Liu \& H. G. Hwang (2011). "Exploring nursing e-learning systems success based on information system success model," CIN - Comput. Informatics Nurs., vol. 29, no. 12, pp. 741-747.

[17] W. S. Lin \& C. H. Wang (2012). "Antecedences to continued intentions of adopting e-learning system in blended learning instruction: A contingency framework based on models of information system success and tasktechnology fit," Comput. Educ., vol. 58, no. 1, pp. 88-99.

[18] Y. Li; Y. Duan; Z. Fu \& P. Alford (2012). "An empirical study on behavioural intention to reuse e-learning systems in rural China,” Br. J. Educ. Technol., vol. 43, no. 6, pp. 933-948.

[19] A. Tella (2012). "System-related factors that predict students' satisfaction with the blackboard learning system at the University of Botswana," African J. Libr. Arch. Inf. Sci., vol. 22, no. 1, pp. 41-52. 
[20] S. Alkhalaf; A. T. A. Nguyen; S. Drew \& V. Jones (2013). "Measuring the information quality of e-learning systems in KSA: Attitudes and perceptions of learners," in Advances in Intelligent Systems and Computing, vol. 208 AISC, pp. 787-791.

[21] M. Visser; J. van Biljon \& M. Herselman (2012). “Modeling management information systems' success,” no. October, p. 384.

[22] R. Halonen; H. Thomander \& E. Laukkanen (2010). "DeLone \& McLean IS success model in evaluating knowledge transfer in a virtual learning environment,” Int. J. Inf. Syst. Soc. Chang., vol. 1, no. 2, pp. 36-48.

[23] B. Wu \& C. Zhang (2014). "Empirical study on continuance intentions towards E-Learning 2.0 systems," Behav. Inf. Technol., vol. 33, no. 10, pp. 1027-1038.

[24] N. Thiongo \& C. Achebe (2001). "Critical success factors for adoption of web-based learning management systems in Tanzania,” JInternational J. Educ. Dev. using Inf. Commun. Technol., vol. 210, no. 1, p. 300.

[25] Y. M. Huang; Y. H. Pu; T. S. Chen \& P. S. Chiu (2015). "Development and evaluation of the mobile library service system success model A case study of Taiwan,” Electron. Libr., vol. 33, no. 6, pp. 1174-1192.

[26] C. C. Chang; C. Liang; K. M. Shu \& Y. C. Chiu (2015). "Alteration of influencing factors of e-learning continued intention for different degrees of online participation,” Int. Rev. Res. Open Distance Learn., vol. 16, no. 4, pp. 3361.

[27] Y. Arshad; M. Azrin \& S. N. Afiqah (2015). "The influence of information system success factors towards user satisfaction in universiti teknikal Malaysia Melaka,” ARPN J. Eng. Appl. Sci., vol. 10, no. 23, pp. 18155-18164.

[28] Y. Yosep (2015). "Analysis of Relationship between Three Dimensions of Quality, User Satisfaction, and ELearning Usage of Binus Online Learning," CommIT (Communication Inf. Technol. J., vol. 9, no. 2, p. 67.

[29] Y. S. Wang et al. (2016). "A conceptual model for assessing blog-based learning system success in the context of business education,” Int. J. Manag. Educ., vol. 14, no. 3, pp. 379-387.

[30] M. A. Almaiah; M. M. A. Jalil \& M. Man (2016). "Empirical investigation to explore factors that achieve high quality of mobile learning system based on students' perspectives,” Eng. Sci. Technol. an Int. J., vol. 19, no. 3, pp. 1314-1320.

[31] R. Sami Khudhair (2016). “An empirical test of information system success model in a University’s electronic services," Adv. Nat. Appl. Sci., vol. 10, no. 12, pp. 1-10.

[32] M. N. Masrek \& J. E. Gaskin (2016). "Assessing users satisfaction with web digital library: the case of Universiti Teknologi MARA,” Int. J. Inf. Learn. Technol., vol. 33, no. 1, pp. 36-56.

[33] J. Hu \& Y. Zhang (2016). "Chinese students' behavior intention to use mobile library apps and effects of education level and discipline," Libr. Hi Tech, vol. 34, no. 4, pp. 639-656.

[34] A. I. Alzahrani; I. Mahmud; T. Ramayah; O. Alfarraj \& N. Alalwan (2019). "Modelling digital library success using the DeLone and McLean information system success model," J. Librariansh. Inf. Sci., vol. 51, no. 2, pp. 291-306.

[35] Q. Zheng \& C. Y. Liang (2017). "The path of new information technology affecting educational equality in the new digital divide-based on information system success model," Eurasia J. Math. Sci. Technol. Educ., vol. 13, no. 7, pp. 3587-3597.

[36] B. A. Y. Al-Nassar (2017). "The influence of service quality in information system success model as an antecedent of mobile learning in education organisations: Case study in Jordan,” Int. J. Mob. Learn. Organ., vol. 11, no. 1, pp. 41-62.

[37] A. Dos Santos; A. J. Santoso \& D. B. Setyohadi (2017). "The analysis of academic information system success: A case study at Instituto Profissional de Canossa (IPDC) Dili timor-leste,” Proc. - 2017 Int. Conf. Soft Comput. Intell. Syst. Inf. Technol. Build. Intell. Through IOT Big Data, ICSIIT 2017, vol. 2018-Janua, pp. 196-2017.

[38] T. K. Yu \& T. Y. Yu (2010). "Modelling the factors that affect individuals - utilisation of online learning systems: An empirical study combining the task technology fit model with the theory of planned behaviour," Br. J. Educ. Technol., vol. 41, no. 6, pp. 1003-1017.

[39] A. H. Aldholay; O. Isaac, Z. Abdullah \& T. Ramayah (2018). "The role of transformational leadership as a mediating variable in DeLone and McLean information system success model: The context of online learning usage in Yemen," Telemat. Informatics, vol. 35, no. 5, pp. 1421-1437.

[40] S. Ghazal; H. Aldowah; I. Umar \& B. Bervell (2018). "Acceptance and satisfaction of learning management system enabled blended learning based on a modified DeLone-McLean information system success model," Int. J. Inf. Technol. Proj. Manag., vol. 9, no. 3, pp. 52-71.

[41] Y. Y. Wang; Y. S. Wang; H. H. Lin \& T. H. Tsai (2019). "Developing and validating a model for assessing paid mobile learning app success," Interact. Learn. Environ., vol. 27, no. 4, pp. 458-477.

[42] F. Xu \& J. T. Du (2018). "Factors influencing users' satisfaction and loyalty to digital libraries in Chinese universities," Comput. Human Behav., vol. 83, pp. 64-72.

[43] A. H. Aldholay; Z. Abdullah; T. Ramayah; O. Isaac \& A. M. Mutahar (2018). "Online learning usage and performance among students within public universities in Yemen,” Int. J. Serv. Stand., vol. 12, no. 2, pp. $163-179$.

[44] C. L. Gan \& V. Balakrishnan (2018). "Mobile technology in the classroom: What drives student-lecturer interactions?,” Int. J. Hum. Comput. Interact., vol. 34, no. 7, pp. 666-679. 
[45] A. Aldholay; O. Isaac; Z. Abdullah; R. Abdulsalam \& A. H. Al-Shibami (2018). "An extension of DeLone and McLean IS success model with self-efficacy: Online learning usage in Yemen,” Int. J. Inf. Learn. Technol., vol. 35, no. 4, pp. 285-304.

[46] L. Y. Chaw \& C. M. Tang (2018). "What makes learning management systems effective for learning?," J. Educ. Technol. Syst., vol. 47, no. 2, pp. 152-169.

[47] P. Ke \& F. Su (2018). "Mediating effects of user experience usability: An empirical study on mobile library application in China," Electron. Libr., vol. 36, no. 5, pp. 892-909.

[48] M. Alksasbeh; M. Abuhelaleh; M. A. Almaiah; M. Al-Jaafreh \& A. A. Karaka (2019). "Towards a model of quality features for mobile social networks apps in learning environments: An extended information system success model," Int. J. Interact. Mob. Technol., vol. 13, no. 5, pp. 75-93.

[49] Stefanus \& T. Mauritsius (2019). “A study on senior high school students' acceptance of mobile learning management system,” J. Theor. Appl. Inf. Technol., vol. 97, no. 13, pp. 3638-3649.

[50] M. Hermita; Farida; E. S. Margianti \& R. Fanreza (2019). "The determinants and impact of system usage and satisfaction on e-learning success and faculty-student interaction in indonesian private universities," Malaysian J. Consum. Fam. Econ., vol. 23, pp. 85-99.

[51] S. A. Albelali \& A. A. Alaulamie (2019). "Gender differences in students' continuous adoption of mobile learning in Saudi higher education,” 2nd Int. Conf. Comput. Appl. Inf. Secur. ICCAIS 2019, pp. 1-5.

[52] Fitriati, A.; Pratama B. C.; Tubastuvi N. \& Anggoro S. (2020). "The study of DeLone-McLean information system success model: The relationship between system quality and information quality,", Journal of Theoretical and Applied Information Technology, pp. 477-483.

[53] E. Y. Lee \& Y. J. J. Jeon (2020). "The difference of user satisfaction and net benefit of a mobile learning management system according to self-directed learning: An investigation of cyber university students in hospitality," Sustain., vol. 12, no. 7, pp. 1-13.

[54] J. Dalle; D. Hastuti; Mahmud; I. Prasetia \& Baharuddin (2020). "DeLone and McLean model evaluation of information system success: A case study of master program of civil engineering universitas lambung mangkurat," Int. J. Adv. Sci. Technol., vol. 29, no. 4 Special Issue, pp. 1909-1919.

[55] M. Salam \& M. S. Farooq (2020). "Does sociability quality of web-based collaborative learning information system influence students' satisfaction and system usage?,” Int. J. Educ. Technol. High. Educ., vol. 17, no. 1.

[56] J. H. L. Koh \& R. Y. P. Kan (2020). "Perceptions of learning management system quality, satisfaction, and usage: Differences among students of the arts," Australas. J. Educ. Technol., vol. 36, no. 3, pp. 26-40.

[57] M. K. Al-Kofahi; H. Hassan \& R. Mohamad (2020). "Information systems success model: A review of literature," Int. J. Innov. Creat. Chang., vol. 12, no. 10, pp. 104-128. 